\title{
ACADEMIC RESEARCH: THE NIGERIAN PRISON EXPERIENCE
}

\author{
Temitope Aroyewun ${ }^{1 *}$, 0000-0001-5075-4802, \\ Khadijah Aroyewun-Adekomaiya ${ }^{2}$, 0000-0002-4881-7656 \\ ${ }^{1}$ Universiti Pendidikan Sultan Idris, 35900 Tanjung Malim, Perak, Malaysia \\ ${ }^{2}$ De Montfort University, The Gateway Leicester, United Kingdom \\ 'Corresponding author: Temitope Aroyewun, aroyewun@fpm.upsi.edu.my
}

Received: 12. 22. 2021

Accepted: 01. 24. 2022

\begin{abstract}
Conducting research in the prisons has its ups and downs. Majority of time, researchers face stress, rigor and challenges. It is documented that data collected in the prison shows poor response and high attrition rate. This article intends to share practical experience from the research carried out titled: Minnesota Multiphasic Personality Inventory -2- Restructured Form (MMPI-2-RF) profile of prisoners in Southwestern Nigeria and to showhow attrition rate and research bias can be managed and how prisoners can be recruitedwithout the use of coercion. It was found that the factors that cause a high rate of wear andtear analyzed the questionnaire at length, the cause being the ambiguity of the questionsand the desire of the respondents to thank the researchers. Therefore, it is necessary forresearchers to use questionnaires with fewer items, the language of the questionnaire shouldbe easy to understand and researchers should be careful of being sentimental with theprisoners.
\end{abstract}

Keywords: Data collection, MMPI-2-RF, practical experience, prisoners, Southwestern Nigeria.

Rezumat. Efectuarea cercetărilor în închisori are suișuri și coborâșuri. De cele mai multe ori, cercetătorii se confruntă cu stres, rigoare și provocări. Este documentat, că datele culese în închisoare arată un răspuns slab și o rată mare de uzură. Acest articol își propune să împărtășească experiența practică din cercetarea efectuată intitulată: Minnesota Multiphasic Personality Inventory -2- Profilul restructured Form (MMPI-2-RF) al prizonierilor din sudvestul Nigeriei și să arate cum pot fi gestionate rata de uzură și părtinirea cercetării, dar și cum prizonierii pot fi recrutați fără utilizarea constrângerii. S-a constatat că factorii care provoacă o rată ridicată de uzură au analizat îndelungat chestionarul, cauza fiind ambiguitatea întrebărilor și dorința respondenților de a le mulțumi cercetătorilor. Prin urmare, este necesar ca cercetătorii să folosească chestionare cu mai puține itemi, limbajul chestionarului ar trebui să fie ușor de înțeles și cercetătorii ar trebui să aibă grijă să fie sentimentali cu deținuții.

Cuvinte cheie: Colectare de date, MMPI-2-RF, experiență practică, prizonieri, Sud-Vestul Nigeriei. 


\section{Introduction}

Academic research is a careful and systematic investigation aimed at seeking truth and new knowledge for the purpose of development which can be carried out anywhere, the prisons inclusive. Academic research in the prison is to inform practice, increase safety, support rehabilitation, and understand behavioural and psychological changes. The basic components of an academic research in the prison are good approach, good logistics and intent to ensure good outcome but conducting research in the prison is of no easy task [1]. In many situations, individuals collecting data in the prison often complain about the protocol, rigor and uneasiness of the process. More complaint is given due to the poor response and high attrition rate of data collected in the prisons from the inmates.

The prison setting has been documented to be a sensitive and special environment [2] while the Nigerian prison is not left out. The Nigerian prison has its peculiarity and many things seem to go wrong with the system. There are prison overcrowding, inadequate health care service (physical and psychological), poor quality food, lack of toiletries and household items, financial constraint, incidence of missing case files, sexual immorality, recidivism and extortion. These and more make the prisoners vulnerable population at risk for psychological illness, violence, substance abuse and infectious diseases. As a result, the prisons are important sites for public and mental health research [2]. Consequently, academic research in the prison seems to be difficult and stressful and could result in few valid response questionnaires. With a good approach and logistics, the stress may be reduced. Taking from the experience of the authors in academic prison research on the thesis titled: Minnesota Multiphasic Personality Inventory -2- Restructured Form (MMPI-2-RF) profile of prison inmates in Southwestern Nigeria, the following suggestions on the process to take include and not limited to getting ethical approval to collect data; knowing the rules guiding data collection like no pictures; no video or voice recording; the cross-checking of the instruments/questionnaire by officials of the correctional services to be sure it does not contain any information they may not be comfortable with. The ability of the prisoners to participate voluntarily and respond adequately to interviews and/or questionnaires as prisoners may not read the questionnaire before answering, and the use of incentives [3].

\section{Ethical considerations}

The Nigerian prisoners are under the supervision and protection of the government by Nigerian Correctional Services under the Ministry of interior, so it becomes imperative for the government to do everything within its power to secure and prevent prisoners from both internal and external challenges and also protect the researcher from harm from the prisoners.

There are certain steps that need to be followed to make access into the prison yard easy. First, the investigator has to take the research proposal to any government approved ethical board (like the Ministry of Health or Nigerian Defense Academy) to evaluate for any ethical issues, advice accordingly and issue a certificate of approval. Then, it is expected that the researcher obtains a letter of introduction from the department of the institution he or she is from. This letter is typed and signed on a departmental letter head and addressed to the Controller of the prison of interest. A new policy in the prison service allows researchers to get approval almost immediately. Though, before getting the approval the information on what you want to research on, the methodology, procedure intended to take and research 
tool/instrument/questionnaire will be clearly stated in the letter, it will be good if a copy of the proposal of the research is submitted alongside the letter to facilitate quick approval.

Also, the investigator will be interviewed by the prison service and the response given will determine the readiness, need and importance for the research. An approval letter will be given to the investigator from the office of the Controller stating their terms of approval. On taking the letter to the prison yard, the days, time and avenues for the research will be communicated to the investigator. Prison officers with be attached to the investigator for protection from possible harm and to assist with the process. Many a times, the investigator may not have more than two to three hours with the inmates, depending on the scope of research and how lengthy the questionnaire, time management becomes imperative.

The time allocated incorporates opening up of some prisoners because not all of them will be unlocked at the same time. It is done this way to enable control of prisoners by the officers. Also, the meeting with prisoners to encourage them to participate, addressing them and administering or interviewing them falls within this timing. It becomes obvious that an academic prison researcher needs to be patient when collecting data and conducting the whole research. Depending on the target sample, it may take months or year(s) to complete data collection from the prison. The Nigerian prison service is not so rigid and difficult if all protocols are duly observed and the researcher adheres to service rules. Ethical issues like respondents' consent, confidentiality, and debriefing are vital amongst others and they must be considered.

\section{Research Bias}

Being heavily pregnant during data collection, many of the prisoners usually showed care and pity that I had to go through such rigor in my state. This recruited many prisoners for me and it may have also interfered with their answering pattern as one of them mentioned to me that "I will show you mercy by making sure I answer every question rightly". However, in the end I lost $65.18 \%$ of my data. The loss was because the profiles were invalid and uninterpretable according to the protocol validity screening of the Minnesota Multiphasic Personality Inventory-2-Restructured Form (MMPI-2-RF). Though, one will wonder why such a large loss?

Prisoners produce high attrition rate as explained by Sudman \& Bradbury [4]. They opined that this could be an act of social desirability bias. Social desirability bias is the respondents desire to please the researcher, whether the researcher is there or not. It could also be with the aim of a secondary gain as mentioned by Ben-Porath \& Tellegen [5]; they argued that offenders malinger or over-report for secondary gains, especially towards getting less severe criminal sentences, or simply to attract attention or sympathy. For this particular research, the secondary gain may have been the toiletries given to only those that participated to appreciate them for their time and participation. With the enticement, the recruited participants were many; it also increased the attrition rate.

Schwarz (1987) also identified another possible cause to be response effects which could have emerged from sample bias, ambiguity of questions or respondents' interpretation of questions [6]. The language style of the MMPI-2-RF contains some idioms and words that majority of Nigerians are not commonly used to or familiar with [3] which was a factor in the way the prisoners interpreted the questions which in turn affected their response. Some did not understand the questions at all. An Example was in question 1: "I like mechanic magazines", question 30 which states "most of the time I feel blue". Another was question 
130 which stated "I brood a great deal". Others are question 145: "I would like to be a florist", question 148: "I very much like hunting", question 162: "I seldom or never have dizzy spells", question 217: "I very seldom have spells of the blues". Though, one way to control for the ambiguity of some of the questions was to translate the instrument into Nigerian native languages. This was considered for the research as the MMPI-2-RF was translated by professional translators alongside the authors from English language to Hausa, Igbo and Yoruba languages and back to English and to validate. The translators grew up with these languages and are very conversant with the cultures. But with this, very many of the prisoners could not read their own languages. This proves that many of the prisoners were not literarily proficient. These have implications for the type of data collection method you may want to adopt. One way to solve this challenge is to acculturate standardized scales, use questionnaires with simple, clear languages and incorporate interview for broadness and debt of information.

\section{Assessment tool}

The assessment tool to be adopted is very crucial for the success of research outcome. The assessment tool to be used must be well standardized with strong coefficient alphas and validity scales that can prove the usefulness of the answered questionnaires. The authors utilized MMPI-2-RF. MMPI-2-RF is a widely used personality and psychopathology tool in criminal justice system by forensic psychologists amongst other psychological tests [7]. The MMPI-2-RF is a 338 item inventory with countless empirical works from around the world and efficient validity scales. The validity scales can detect a test-taker approach [5].

The inventory has standard rules; it was these rules that helped with separating the useful from the faulty profiles which could have watered the final results. The rules were:

(1) For a profile to be given consideration, $90 \%$ of the questions must be attempted. The authors lost 63 profiles due to incomplete answering pattern.

(2) The t-scores on the validity scales VRIN and TRIN cannot be equal to or exceed 80. It was based on this rule that majority of the profiles were lost.

Nine hundred and eighty-two (982) prisoners were the initial participants. The samples reduced to nine hundred and nineteen (919) after removing profiles based on rule one. Five hundred and fifty-nine (599) were lost to VRIN and TRIN t-scores above 80 which brought down the total valid, interpretable and sound profiles to three hundred and twenty (320) which coincidentally is within the sample size needed as the total population of the prisoners in the Southwestern Nigeria was estimated 16,000 as at March 2017 when the data was collected. An explanation for the high attrition rate was that some prisoners approached the answer with consistent positive responses while some consistently gave negative responses $[3,8]$.This is the outcome of using a world class, sophisticated and empirically rich research assessment tool much less if an ordinary assessment tool was used. The academic researcher needs to be careful with the tool to be used.

There is substantial evidence that data from surveys and interviews are problematic, prisoners answering surveys persistently underreport socially undesirable attributes and over-report socially desirable attributes [8]. This was the case of our research using the MMPI2-RF, a good number of prisoners presented themselves in a favorable light by withholding any petty faults and shortcomings that most individuals endorse and they over reported their symptoms with the aim of getting pity and considerations [3] (see Table 1). Not that the symptoms were not present but they were exaggerated. 
Table 1

Patterns of offender over-reporting and under-reporting on Protocol validity

\begin{tabular}{|c|c|c|c|c|c|c|c|c|}
\hline & & F-r & Fp-r & Fs & FBS-r & RBS & L-r & K-r \\
\hline T-Score & & $\geqslant 90$ & $\geqslant 80$ & $\geqslant 80$ & $\geqslant 100$ & $\geqslant 80$ & $\geqslant 70$ & $\geqslant 70$ \\
\hline \multirow{2}{*}{$\begin{array}{l}\text { Over - under } \\
\text { reporting }\end{array}$} & $\mathbf{N}$ & 97 & 154 & 60 & 5 & 40 & 164 & 6 \\
\hline & $\%$ & $30.3 \%$ & $48.1 \%$ & $18.8 \%$ & $1.6 \%$ & $12.5 \%$ & $51.3 \%$ & $1.9 \%$ \\
\hline \multirow{2}{*}{$\begin{array}{l}\text { Over - } \\
\text { reporting } \\
\text { only }\end{array}$} & $\mathbf{N}$ & 58 & 83 & 42 & 8 & 24 & 0 & 0 \\
\hline & $\%$ & $18.1 \%$ & $25.9 \%$ & $13.1 \%$ & $2.5 \%$ & $7.5 \%$ & $0.0 \%$ & $0.0 \%$ \\
\hline \multirow{2}{*}{$\begin{array}{l}\text { Under - } \\
\text { reporting } \\
\text { only }\end{array}$} & $\mathbf{N}$ & 0 & 0 & 0 & 0 & 0 & 51 & 1 \\
\hline & $\%$ & $0.0 \%$ & $0.0 \%$ & $0.0 \%$ & $0.0 \%$ & $0.0 \%$ & $15.9 \%$ & $.3 \%$ \\
\hline \multirow{2}{*}{ Normal } & $\mathbf{N}$ & 0 & 0 & 0 & 0 & 0 & 0 & 0 \\
\hline & $\%$ & $0.0 \%$ & $0.0 \%$ & $0.0 \%$ & $0.0 \%$ & $0.0 \%$ & $0.0 \%$ & $0.0 \%$ \\
\hline \multirow[b]{2}{*}{ Total } & $\mathbf{N}$ & 155 & 237 & 102 & 13 & 64 & 215 & 7 \\
\hline & $\begin{array}{l}\% \text { of } \\
\text { Total }\end{array}$ & $48.4 \%$ & $74.1 \%$ & $31.9 \%$ & $4.1 \%$ & $20.0 \%$ & $67.2 \%$ & $2.2 \%$ \\
\hline
\end{tabular}

The criteria for over-reporting are T-scores on F-r $\geqslant 120$, Fp- $r \geqslant 100$, Fs $\geqslant 100$, FBS- $r \geqslant$ 100; while that of under-reporting are T-scores on $L-r \geqslant 80$ and $K-r \geqslant 70$. The percent of offenders that over reported were: F-r (48.4\%), Fp-r (74.1\%), Fs (31.9\%), FBS-r (1.6\%) and RBS (12.5\%) respectively. The offenders who under-reported were: L-r (67.2\%) and K-r (2.2\%).

\section{Sampling Technique}

The sampling technique of any research is one of the features that determines the methodology and has implication for the research outcome. Randomized sampling technique is usually of great interest to academic researchers because of its strong generalization feature but the reality of some settings makes it impossible to use, an example is the prison. A combination of probabilistic (simple randomization) and non-probabilistic sampling technique (purposeful or convenience or consecutive) may be used but the most common sampling techniques adopted in prison settings are usually non-probabilistic [9].

Using the research carried out by the authors as an example, the scope of the authors' research was in Southwestern Nigeria and with the aid of a simple random technique (that is, balloting), the researchers were able to pick Lagos, Ogun, Oyo and Osun amongst all other southwestern states. Thereafter, a purposeful selection of prison in each state was made after considering the logistics of proximity to the prisons, assistance, support from the prison officers and readiness of the prisoners to participate. A consecutive sampling technique was adopted at the participant selection stage. The consecutive sampling came to play after prisoners were gathered in a class, they were addressed by the authors and they participated in the research as they picked interest for as long as they met the inclusion criteria. This technique was adopted because few prisoners were unlocked at a particular timing; many of them were uninterested in the research. The population needed was a thousand and the time 
allocated for the researcher by the authority was short for the type of instrument used. The instrument was the MMPI-2-RF, a 338 item questionnaire and was presented to participants alongside the demographics and criminal history index. This method was adopted for all the prisons visited. Consequently, because of the sampling technique adopted and the nature of the instrument used the resultant statistical analysis was non-parametric [3].

\section{Incentives}

The issue of giving respondents incentives is highly argued by researchers: some are of the view that it will alter the response of the participant $[10,11]$; some argue it may be given but the respondent should not be aware of it; some are of the opinion that they can be told because it is accepted by all that it is a way to enhance recruitment $[10,12,13]$ and as a gratitude for their time and energy depending on the scope, rigor and time span of the research $[14,15]$. The nature of the research and the participants may determine whether incentives will or will not be given [13].

Little or no motivation, cognitive impairment, poor reading and language knowledge, understanding skill and low intelligence level may affect a test-taker's ability to answer appropriately to the test items [5]. Motivation can be said to be synonymous to incentives in this regard. Specifically, giving prisoners incentives for participating is quite relative but most preferable. The reason is, in Nigeria, the prisoners are overwhelmed with hardship. There is prison congestion, insufficient food, little or no toiletries like bathing and washing soaps, tissues, tooth paste and even clothing. The welfare department of the Prison service usually solicits for these materials through NGOs, religious organizations amongst others. The government funds them but it is not sufficient.

Most of the time, the authors were always allowed to carry in incentives (bathing soap, detergents, toothpaste and biscuits). Only those that participated in the research were given. Usually the officers asked if the researcher had anything for the prisoners. At times, to make the work a whole lot easy prison officers attached to the researcher were given incentives too so as to encourage and appreciate them. In all, the more incentive given the more relaxed the prisoners were, the more friendly the atmosphere was and the more reliable and valid the profiles were. Prisoners in medium prisons were most interested and deserving of the incentives than prisoners in the maximum prisons [13], this I found to be so. Majority of prisoners in the maximum prison were quite well fed and they looked tidy. Probably because majority were lifer, on death-row or long term imprisonment so anything to make life quite easy for them was adopted while the medium facility was too congested, they smell out of little or no toiletries to wash and bath with and no extra clothes to wear.

\section{Conclusion}

The prison is a beautiful sight for research as many more hypotheses arise when researching in the prison. Intending academic researcher need to take necessary ethical steps to have access into the prison yards. They have to understand the importance of an assessment tool that is viable to detect poor answering pattern and the need to use more than one assessment methods, understand that there are reported high attrition rate amongst inmates and possible ways to address it, and need for incentives because of the nature of the prison. Having catered for all of these factors, the researcher can therefore hope for a good outcome from the research. 


\section{References}

1. Michelle S. What is a Good Prison Research. Canada:York University, 2018.

2. Apa Z.L., Bai R., Mukherejee D.V., Herzig C.T., Koenigsmann C., Lowy F.D., Larson E.L. Challenges and strategies for research in prisons. In: Public Health Nursing. 2012, 29 (5), pp. 467 - 472.

3. Aroyewun T.F. Minnesota Multiphasic Personality Inventory Profile of Prison Inmates in Southwestern Nigeria: Doctoral Thesis.Ibadan (Nigeria): University of Ibadan, 2021.

4. Sudman S. \& Bradburn N. Asking questions: a practical guide to survey design. San Francisco:.Jossey-Bass, 1982.

5. Ben-Porath Y.S. \& Tellegen A. MMPI-2-RF (Minnesota Multiphasic Personality Inventory-2 Restructured Form): User's guide for reports (2nd edition). Minneapolis, MN: University of Minnesota Press, 2011.

6. Schwarz N. Response effects in surveys. In: Hippler, H.J., Schwarz, N. \& Sudman, S., ed, Social information processing and survey methodology. NewYork : Springer-Verlag,1987, pp. 102 - 122.

7. Archer R.P., Buffington-Vollum, J.K., Stredny, R.V., Handel, R.W. A survey of psychological test use patterns among forensic psychologists.In: Journal of Personality Assessment. 2006, 87(1), pp. 84 - 94.

8. $\quad$ Phillips N. Knowledge From What? Chicago :Rand McNally, 1972.

9. Abbott, P., DiGiacomo, M., Magin, P. \& Wendy, H. A Scoping Review of Qualitative Research Methods Used with People in Prison. In: International Journal of Qualitative Methods. 2018, 17, pp. 1 - 5.

10. Bentley J. P. \& Thacker P.G. The Influence of Risk And Monetary Payment On The Research Participation Decision Making Process. In: Journal of Medical Ethics. 2004, 30 (3), pp. 293 - 298.

11. Largent E.A., Grady C., Miller F.G \& Wertheimer, A. Money, Coercion, and undue Inducement: A survey of Attitudes about Payments to Research Participants. In: Institutional Review Board. 2012, 34(1), pp. 1 - 8.

12. Tishler C.L. \& Bartholomae S. The recruitment of normal healthy volunteers: a review of the literature on the use of financial incentive. In: Journal of Clinical Pharmacology. 200242 (4), pp. 365 - 375.

13. Stunkel L. \& Grady, C. More than the money: a review of literature examining healthy volunteer motivations. In: Contemporaray Clinical Trials. 2011, 32 (3), pp. 342 - 352.

14. Emmanuel E.J., Wendler D. \& Grady C. What makes clinical research ethical? In: Journal of the American Medical Association. 2000,283 (20), pp. 2710 - 2711.

15. Roberts D. G. Recreating Experiences: Improving the Validity of Data. In: Evaluation Journal of Australasia. 2005, 4 (1\&2), pp. 44 - 51. 